\title{
Inhibition of NF-kB prevents high glucose-induced proliferation and plasminogen activator inhibitor-1 expression in vascular smooth muscle cells
}

In-Kyung Jeong ${ }^{1,8}$, Da Hee Oh' ${ }^{1}$, Seung-Joon Park ${ }^{3}$, Ja-Heon Kang ${ }^{2}$, Sunshin Kim ${ }^{4}$, Myung-Shik Lee ${ }^{5}$, Myung-Jun Kim ${ }^{6}$, Yoo-Chul Hwang ${ }^{1}$, Kyu Jeong Ahn', Ho-Yeon Chung', Min-Kyung Chae ${ }^{7}$ and Hyung-Joon Yoo ${ }^{7}$

\author{
${ }^{1}$ Department of Endocrinology and Metabolism \\ ${ }^{2}$ Department of Ophthalmology \\ Kyung Hee University Hospital at Kangdong \\ ${ }^{3}$ Department of Pharmacology \\ Kyung Hee University College of Medicine \\ Seoul 134-727, Korea \\ ${ }^{4}$ Carcinogenesis Branch \\ Division of Cancer Biology \\ National Cancer Center \\ Goyang, Korea \\ ${ }^{5}$ Department of Endocrinology and Metabolism \\ Samsung Medical Center \\ Sungkyunkwan University School of Medicine \\ Seoul, Korea \\ ${ }^{6}$ Department of Physiology \\ College of Medicine \\ The Catholic University of Korea \\ Seoul, Korea \\ ${ }^{7}$ Department of Internal Medicine \\ Hangang Sacred Heart Hospital \\ Hallym University School of Medicine \\ Seoul, Korea \\ ${ }^{8}$ Corresponding author: Tel, 82-2-440-6126; \\ Fax, 82-2-440-6295; E-mail, jik1016@khu.ac.kr \\ http://dx.doi.org/10.3858/emm.2011.43.12.079
}

Accepted 4 October 2011

Available Online 6 October 2011

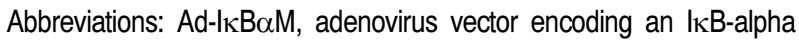
mutant; PAI-1, plasminogen activator inhibitor-1; VSMC, vascular smooth muscle cell

\begin{abstract}
Recent epidemiologic studies clearly showed that early intensive glucose control has a legacy effect for preventing diabetic macrovascular complications. However, the cellular and molecular processes by which high glucose leads to macrovascular complica-
\end{abstract}

tions are poorly understood. Vascular smooth muscle cell (VSMC) dysfunction due to high glucose is a characteristic of diabetic vascular complications. Activation of nuclear factor- $\mathrm{KB}$ (NF-kB) may play a key role in the regulation of inflammation and proliferation of VSMCs. We examined whether VSMC proliferation and plasminogen activator inhibitor-1 (PAl-1) expression induced by high glucose were mediated by NF-kB activation. Also, we determined whether selective inhibition of NF- $\mathrm{KB}$ would inhibit proliferation and PAI-1 expression in VSMCs. VSMCs of the aorta of male SD rats were treated with various concentrations of glucose (5.6, $11.1,16.7$, and $22.2 \mathrm{mM}$ ) with or without an inhibitor of NF- $k B$ or expression of a recombinant adenovirus vector encoding an IKB- $\alpha$ mutant (Ad-IKB $\alpha M)$. VSMC proliferation was examined using an MTT assay. PAl-1 expression was assayed by real-time PCR and PAl-1 protein in the media was measured by ELISA. NF- $\mathrm{KB}$ activation was determined by immunohistochemical staining, NF- $\mathrm{kB}$ reporter assay, and immunoblotting. We found that glucose stimulated VSMC proliferation and PAI-1 expression in a dose-dependent manner up to $22.2 \mathrm{mM}$. High glucose $(22.2 \mathrm{mM})$ alone induced an increase in NF-kB activity. Treatment with inhibitors of NF- $\mathrm{KB}$ such as MG132, PDTC or expression of $A d-I_{K} B-\alpha M$ in VSMCs prevented VSMC proliferation and PAl-1 expression induced by high glucose. In conclusion, inhibition of NF-kB activity prevented high glucose-induced VSMC proliferation and PAl-1 expression.

Keywords: cell proliferation; glucose metabolism disorders; muscle, smooth, vascular; NF-кB; plasminogen activator inhibitor 1

\section{Introduction}

Cardiovascular complications are a primary cause of high morbidity and mortality in diabetes mellitus (UK Prospective Diabetes Study [UKPDS] Group, 1998). Recently, the Diabetes Control and Complications Trial (DCCT)/Epidemiology of Diabetes Interventions and Complications (EDIC) study and UKPDS post-trial study clearly showed that early intensive glucose control has a legacy effect for 
preventing diabetic macrovascular complications (DCCT/EDIC Study Research Group, 2005; Holman et al., 2008). However, the cellular and molecular processes by which high glucose leads to macrovascular complications are poorly understood, even though several mechanisms of diabetic vascular complication were suggested (Jeong and King, 2011).

The proliferation of vascular smooth muscle cells (VSMC) is one of the main features of atherosclerosis that are induced by high glucose conditions (Feener and King, 1997). Besides vascular cells, many kinds of inflammatory cells, such as monocytes and macrophages, along with cytokines are involved in atherosclerosis, which leads to the concept that atherosclerosis is an inflammatory disease (Ross, 1999). Nuclear factor $\kappa B(N F-\kappa B)$ regulates transcription of various genes involved in immune and inflammatory responses, growth, and adhesion (Lenardo and Baltimore, 1989). Since the activation of NF-kB was shown to be involved in the human atherosclerotic artery (Brand et al., 1996) or VSMC proliferation sites in the balloon injured artery (Breuss et al., 2002), $N F-\kappa B$ was found to have an important role in atherosclerosis (Landry et al., 1997). Hyperglycemia (Monaco and Paleolog, 2004; Erl et al., 1999) as well as inflammatory cytokines (IL-1 and TNF- $\alpha$ ) (Brand et al., 1997) can activate NF-kB through oxidative stress (Hattori et al., 2000).

Plasminogen activator inhibitor-1 (PAI-1) inhibits fibrinolysis and proteolysis as a physiologic inhibitor of tissue type plasminogen activator or urokinase-like plasminogen activator. Increases of PAI-1 have been observed in cases of thrombosis and fibrosis, obesity, diabetes, and insulin resistance (Meigs et al., 2000; Ma et al., 2004). Increases in PAl-1 mRNA expression were reported in the atherosclerotic artery of type 2 diabetic patients (Pandolfi et al., 2001) and in VSMCs cultured under high glucose conditions (Suzuki et al., 2002) or angiotensin-Il (Lee et al., 2010). However, the signaling pathway involved in high glucose-induced PAl-1 expression and proliferation of VSMCs is not clear even though MAPK or PKC activation is partially involved (Suzuki et al., 2002).

Therefore, it is critical to determine whether the inhibition of proliferation and coagulation in the vasculature can serve as a novel therapeutic strategy to prevent vascular complications of diabetes. We studied the role of NF- $\kappa B$ activation in the proliferation of VSMCs or increases of PAI-1 expression due to high glucose. We also examined whether the inhibition of $\mathrm{NF}-\kappa \mathrm{B}$ by $\mathrm{Adl} \kappa \mathrm{K}-\alpha \mathrm{M}$, an adenoviral vector encoding an $1 \kappa \mathrm{K}-\alpha$ mutant protein as an I $\mathrm{K} \mathrm{B} \alpha$ super-repressor, or inhibitors of NF-KB such

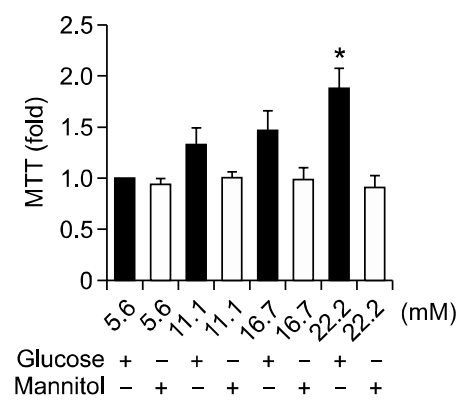

Figure 1. High glucose-induced proliferation of vascular smooth muscle cells (VSMCs). VSMCs were incubated in various concentrations of glucose $(5.6,11.1,16.7$, and $22.2 \mathrm{mM})$ for $48 \mathrm{~h}$. Mannitol was used as an osmotic control. Cell proliferation was measured by an MTT assay. A high concentration of glucose $(22.2 \mathrm{mM})$ significantly increased VSMC proliferation compared to control cells exposed to $5.6 \mathrm{mM}$ glucose ( ${ }^{*} P$ $0.05)$. Same concentrations of mannitol did not increase proliferation of the VSMCs.

as MG132 and PDTC can prevent proliferation or increases in PAl-1 expression induced by high glucose in VSMCs.

\section{Results}

\section{High glucose induces proliferation of VSMCs}

Incubation of VSMCs with various concentrations of glucose $(5.6,11.1,16.7$, and $22.2 \mathrm{mM})$ resulted in an increase of VSMC proliferation in a dose-dependent manner after $48 \mathrm{~h}$ of treatment. This increase was not seen in the osmotic control cells treated with mannitol to maintain the same osmolarity as cell grown in a high concentration of glucose $(22.2 \mathrm{mM})$. We found that $22.2 \mathrm{mM}$ glucose significantly increased VSMC proliferation (Figure 1) compared to control cells exposed to 5.6 mM glucose $(P<0.05)$.

\section{High glucose activates the NF- $\mathrm{kB}$ signaling pathway} Immunohistochemical staining: VSMCs in NG $(5.6$ $\mathrm{mM}$ ) retained NF-kB p65 in the cytoplasm (green fluorescence) with little staining observed in the nuclei (Figure 2A-2). VSMC cultured in HG $(22.2$ $\mathrm{mM}$ ) showed in a significant increase of NF- $\mathrm{kB}$ p65 nuclear translocation (Figure 2A-3) similar to the positive control (TNF- $\alpha$, Figure 2A-1) which contained intense green fluorescence localized in the cell nuclei. Nuclei were stained blue by Hoechest staining.

Luciferase activity: The NF- $\mathrm{kB}$ activity in cells treated for $48 \mathrm{~h}$ with 11.1 and $22.2 \mathrm{mM}$ glucose was 2.8- and 15.7-fold, respectively, greater than that in cells treated with NG $(5.6 \mathrm{mM})$. HG $(22.2 \mathrm{mM})$ significantly increased NF-kB activity $(P<0.001$; 


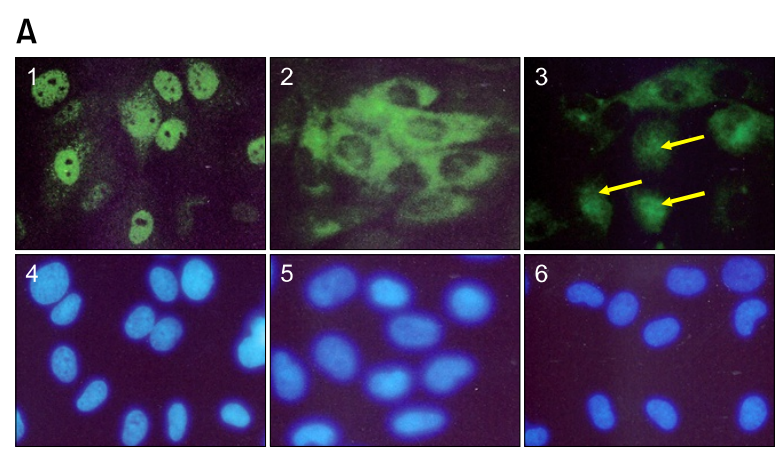

B

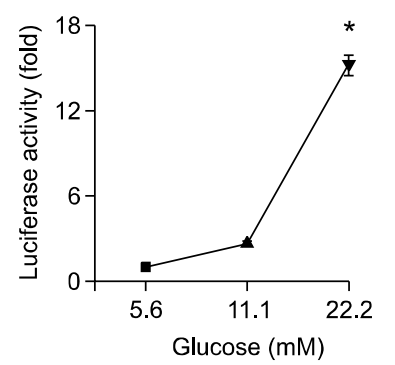

C

1
Time (min) 0 $5 \quad 103060120$
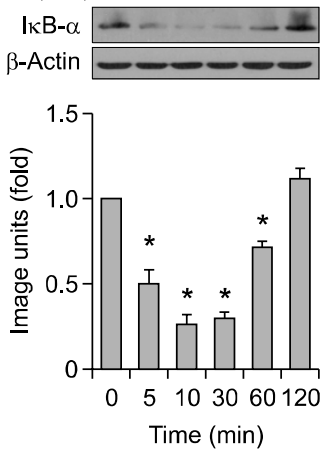

2

Glucose (mM) 5.611 .116 .722 .2
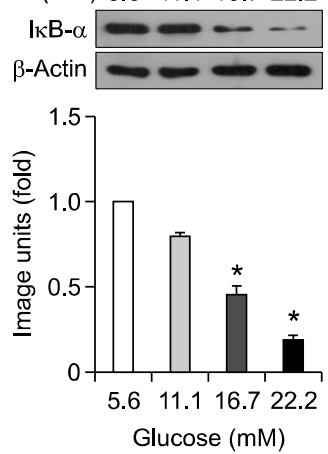

Figure 2. NF-KB activation by a high glucose concentration. (A) The effect of high glucose on the translocation of NF- $\mathrm{KB}$. VSMCs were treated with $10 \mathrm{ng} / \mathrm{ml} \mathrm{TNF-} \alpha$ as a positive control (A-1), normal glucose $(5.6 \mathrm{mM}$, A-2), and high glucose (22.2 mM, A-3). The cells were fixed and subjected to immunohistochemical staining to examine translocation of NF-kB. Nuclei were stained blue by Hoechest staining $(A-4,5,6)$. VSMCs cultured in high glucose $(22.2 \mathrm{mM})$ resulted in a significant increase of NF- $\kappa B$ p65 nuclear translocation (A-3, arrows). (B) The effect of glucose on luciferase activity. VSMCs were transfected with pNFKB-Luc and treated with 5.6, 11.1, and $22.2 \mathrm{mM}$ glucose. High glucose $(22.2 \mathrm{mM})$ significantly induced an increase of luciferase activity in the VSMCs $\left({ }^{*} P<0.001\right)$. (C) The effect of glucose on the expression of $I_{\kappa} B-\alpha$. VSMCs were cultured in high glucose $(22.2 \mathrm{mM})$ for various time periods. Whole cell lysates were subjected to Western immunoblotting to analyze the protein levels of $I_{\kappa} B-\alpha$. Densitometry quantification values (Image J) were measured and shown by fold over the control for each time point. Degradation of $1 \kappa \mathrm{K}-\alpha$ started at $5 \mathrm{~min}$, was maintained until $60 \mathrm{~min}$, and returned to the basal level $120 \mathrm{~min}$ after high glucose (22.2 $\mathrm{mM})$ treatment $(\mathrm{C}-1)$. Also, quiescent VSMCs were treated with various concentrations of glucose for $30 \mathrm{~min}$. The representative immunoblot shows that high glucose (16.7 and $22.2 \mathrm{mM}$ ) significantly induced degradation of $I_{K} B-\alpha(C-2)\left({ }^{*} P<0.05\right)$.
Figure 2B).

Immunoblotting (Western blot): When VSMCs were cultured in $\mathrm{HG}(22.2 \mathrm{mM})$ for various time periods, degradation of $\mathrm{lkB}-\alpha$ started at $5 \mathrm{~min}$, maintained until $60 \mathrm{~min}$, and returned to the basal level 120 min after HG treatment (Figure 2C-1). Also, after treatment with various concentrations $(5.6,11.1,16.7$, and $22.2 \mathrm{mM}$ ) of glucose for $30 \mathrm{~min}$, the high glucose concentrations (16.7 and $22.2 \mathrm{mM}$ ) significantly induced degradation of $\mathrm{lkB}-\alpha$ compared with that of $5.6 \mathrm{mM}$ glucose (Figure 2C-2).

\section{High glucose stimulates PAl-1 mRNA expression and PAl-1 protein secretion into media}

We examined the effects of high glucose on PAI-1 mRNA expression in VSMCs with semi-quantitative RT-PCR and real-time PCR. PAI-1 mRNA was observed at low levels in untreated control VSMCs. After HG (22.2 mM) treatment, PAl-1 mRNA increased at $2 \mathrm{~h}$, peaked at $6 \mathrm{~h}$, and remained constant at $10 \mathrm{~h}$ (Figure $3 \mathrm{~A}$ ).

To evaluate the effects of various concentrations of glucose on PAl-1 gene expression, VSMCs were treated with 5.6, 11.1, 16.7, and $22.2 \mathrm{mM}$ glucose for $6 \mathrm{~h}$. Figure 3B shows that PAl-1 mRNA expression was increased in a glucose concentrationdependent manner. High concentrations of glucose (16.7 and $22.2 \mathrm{mM}$ ) significantly stimulated PAI-1 mRNA expression compared to $5.6 \mathrm{mM}$ glucose treatment $(P<0.05,16.7 \mathrm{mM}$ versus $5.6 \mathrm{mM}$ glucose; $P<0.01,22.2 \mathrm{mM}$ versus $5.6 \mathrm{mM}$ glucose).

The level of PAI-1 protein in the media was measured by ELISA. Figure $3 \mathrm{C}$ shows that the 22.2 $\mathrm{mM} \mathrm{HG}$ stimulated the secretion of PAl-1 protein into media compared with $5.6 \mathrm{mM} \mathrm{NG}$ at 8 $\mathrm{h}$ and $12 \mathrm{~h}$ after treatment $\left({ }^{*} P<0.05,22.2 \mathrm{mM}\right.$ versus $5.6 \mathrm{mM}$ glucose; ${ }^{* \star} P<0.01,22.2 \mathrm{mM}$ versus $5.6 \mathrm{mM}$ glucose in Figure $3 \mathrm{C}$ ).

\section{NF-kB inhibition decreases high glucose-induced proliferation in VSMCs}

Addition of NF- $\kappa B$ inhibitors PDTC $(50 \mu \mathrm{M})$ and MG132 (1 ng/ml) also led to a significant decrease in VSMC proliferation compared to that of cells treated with HG (22.2 mM). Two kinds of NF-kB inhibitors prevented high glucose-induced VSMC proliferation $(P<0.05$ versus HG-treated cells; Figure 4A). Additionally, transfection of Adl $\kappa B-\alpha M$ significantly inhibited high glucose-induced VSMC proliferation $(P<0.05$ versus cells treated with $22.2 \mathrm{mM}$ glucose or $22.2 \mathrm{mM}$ glucose with $\mathrm{Ad} \beta$-gal; Figure 4B). 
A
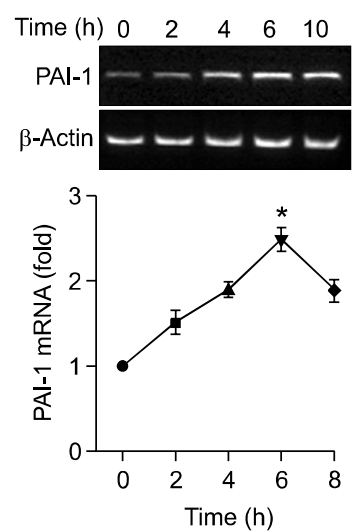

B

Glucose (mM) $5.6 \quad 11.1 \quad 16.7 \quad 22.2$
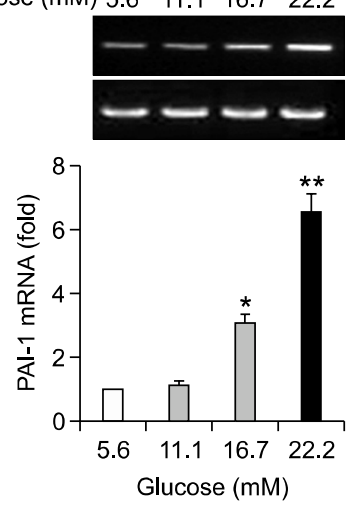

C

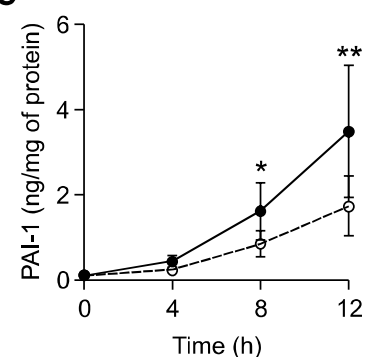

Figure 3. Effects of high glucose on PAl-1 mRNA expression $(\mathrm{A}, \mathrm{B})$ and PAl-1 protein secretion (C). (A) Time-dependent effects of high glucose on PAl-1 mRNA expression. Quiescent cells were stimulated with high glucose $(22.2 \mathrm{mM})$ for the indicated times. PAl-1 mRNA expression was determined by semi-quantitative RT-PCR. PAI-1 mRNA expression started to increase at $2 \mathrm{~h}$, peaked at $6 \mathrm{~h}$, and then decreased after high glucose treatment. (B) Dose-dependent effects of high glucose on PAl-1 mRNA expression. Quiescent cells were stimulated with the indicated concentrations of glucose for $6 \mathrm{~h}$ and were subjected to RT-PCR. High concentrations of glucose (16.7 and $22.2 \mathrm{Mm}$ ) significantly stimulated PAl-1 mRNA expression. ${ }^{* *} P<0.01$ versus $5.6 \mathrm{mM}$ glucose, ${ }^{*} P<$ 0.05 versus $5.6 \mathrm{mM}$ glucose). Data are shown as mean $\times \mathrm{SD}$ from at least four experiments. (C) Time-dependent effects of high glucose on secretion of PAI-1 protein in the media. Synchronized quiescent VSMC cells were treated with DMEM Low Glucose without Penol Red containing 5.6 (open circle) and 22.2 (closed circle) $\mathrm{mM}$ glucose for $4,8,12 \mathrm{~h}$. PAl-1 concentrations of the culture medium were determined using a rat PAl-1 ELISA kit and were expressed as nanograms of active PAI-1 released from VSMC/mg of cell protein. $\left({ }^{*} P<0.05\right.$ versus $5.6 \mathrm{mM}$ glucose, ${ }^{* *} P<0.01$ versus $5.6 \mathrm{mM}$ glucose)

\section{NF- $k B$ inhibition prevents high glucose-induced PAI-1 mRNA expression and PAl-1 protein secretion in VSMC}

High glucose significantly stimulated PAI-1 mRNA expression $(P<0.01$ versus cells treated with 5.6 $\mathrm{mM}$ glucose). Pretreatment with $1 \mathrm{ng} / \mathrm{ml}$ MG132 or $50 \mu \mathrm{M}$ PDTC (Figure 5A) prevented HG-induced PAl-1 mRNA expression $(P<0.05$ versus cells treated with $22.2 \mathrm{mM}$ glucose alone). AdlкB- $\alpha \mathrm{M}$ expression (Figure 5B) also significantly inhibited HG-induced PAI-1 mRNA expression $(P<0.05$
A

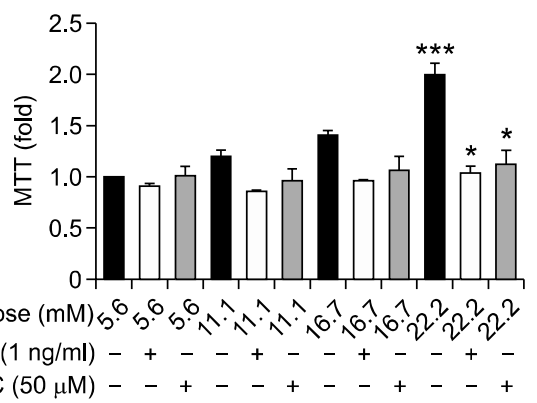

B

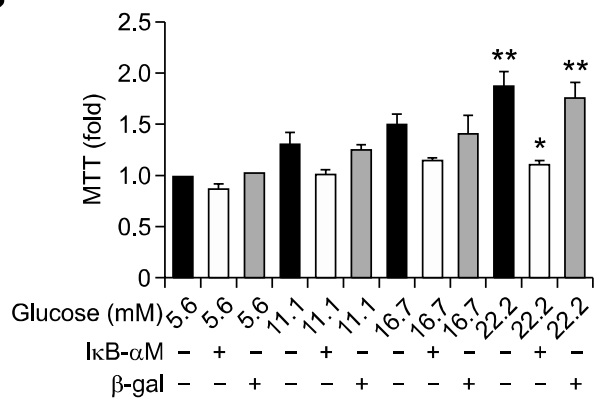

Figure 4. NF- $\mathrm{K} B$ inhibition decreases high glucose-induced proliferation in VSMC. VSMCs were treated with different glucose concentrations (5.6, $11.1,16.7$, and $22.2 \mathrm{mM}$ ) for $48 \mathrm{~h}$ in the presence or absence of NF-KB inhibitors: MG132 (A) or PDTC (A) or transfection of Adl $\kappa B-\alpha M(B)$. (A) Cells were pretreated with MG132 $(1 \mathrm{ng} / \mathrm{ml})$ or PDTC $(50 \mu \mathrm{M})$ for $2 \mathrm{~h}$ and then treated with the indicated concentrations of glucose for $48 \mathrm{~h}$. Cell proliferation was measured by an MTT assay. High glucose (22.2 mM) significantly stimulated proliferation of VSMC ${ }^{* * *} P<0.001$ versus 5.6 $\mathrm{mM}$ glucose). The two NF-kB inhibitors prevented HG-induced VSMC proliferation ( ${ }^{*} P<0.05$ versus treatment with $22.2 \mathrm{mM}$ glucose alone). (B) Adl $\kappa B-\alpha M$ as a $\left.\right|_{\kappa} B \alpha$-super-repressor was transfected into VSMC for $4 \mathrm{~h}$. VSMCs were treated with indicated concentrations of glucose for $48 \mathrm{~h}$. High glucose $(22.2 \mathrm{mM})$ significantly stimulated proliferation of VSMC ( ${ }^{* *} P<0.01$ versus $5.6 \mathrm{mM}$ glucose). Adl $\mathrm{\kappa B}-\alpha \mathrm{M}$ significantly inhibited high glucose-induced VSMC proliferation $\left({ }^{*} P<0.05\right.$ versus VSMCs treated with $22.2 \mathrm{mM}$ glucose or Ad $\beta$-gal transfected cells treated with $22.2 \mathrm{mM}$ glucose with).

versus cells treated with $22.2 \mathrm{mM}$ glucose or 22.2 $\mathrm{mM}$ glucose with $\beta$-gal). HG induced PAl-1 protein secretion was significantly reduced by $1 \mathrm{ng} / \mathrm{ml}$ MG132 or $50 \mu \mathrm{M}$ PDTC (Figure $5 \mathrm{C}$ ).

\section{Discussion}

Our results demonstrated that high glucose stimulated proliferation and PAI-1 expression of rat VSMCs.

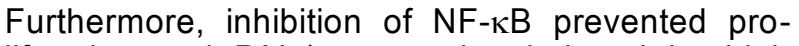
liferation and PAl-1 expression induced by high glucose in VSMCs. We have reported for the first time that both proliferation and PAI-1 expression of

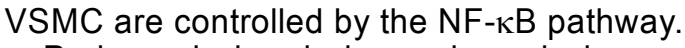

Prolonged chronic hyperglycemia is one of the 
A

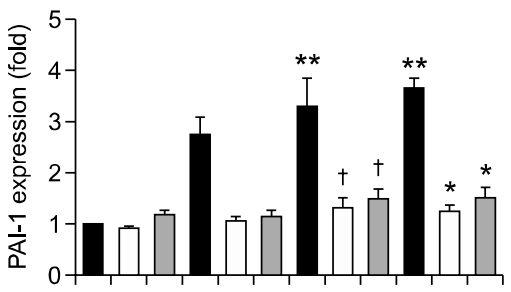

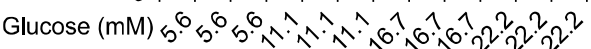
$\operatorname{MG} 132(1 \mathrm{ng} / \mathrm{ml})-+\ldots+\ldots-+-2_{+}$

$\operatorname{PDTC}(50 \mu \mathrm{M})$ - _ + - + $+\ldots+\ldots$

B

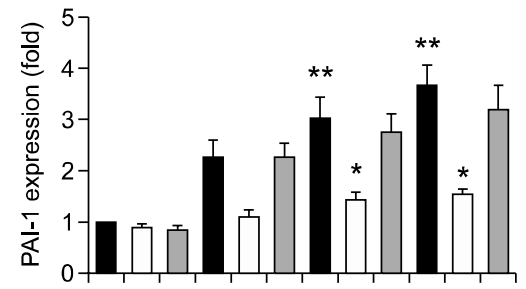

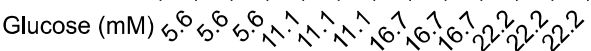

$\mathrm{IkB}-\alpha \mathrm{M}-+-++-+-++$

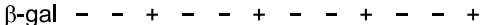

C

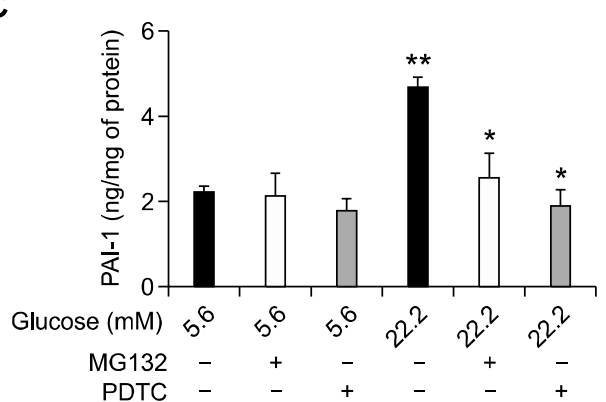

Figure 5. NF- $\kappa B$ inhibition prevents high glucose-induced PAl-1 expression in VSMCs. VSMCs were treated with different glucose concentrations $(5.6,11.1,16.7$, and $22.2 \mathrm{mM})$ for $48 \mathrm{~h}$ in the presence or absence of NF-KB inhibitors, MG132 (A) or PDTC (A) or Adl $\kappa B-\alpha M(B)$. (A) Cells were pretreated with $1 \mathrm{ng} / \mathrm{ml}$ MG132 or $50 \mu \mathrm{M}$ PDTC for $2 \mathrm{~h}$ before being treated with the indicated concentrations of glucose for $6 \mathrm{~h}$. After RNA isolation, PAl-1 mRNA expression was measured by real-time PCR. High glucose significantly stimulated PAI-1 mRNA expression ${ }^{* *} P<$ 0.01 versus $5.6 \mathrm{mM}$ glucose). The two NF-KB inhibitors prevented HG-induced PAl-1 mRNA expression ( ${ }^{*} P<0.05$ versus $22.2 \mathrm{mM}$ glucose alone, ${ }^{\dagger} P<0.05$ versus $16.7 \mathrm{mM}$ glucose alone). (B) High glucose significantly stimulated PAI-1 mRNA expression $\left({ }^{* *} P<0.01\right.$ versus 5.6 $\mathrm{mM}$ glucose). Adl $\kappa \mathrm{B}-\alpha \mathrm{M}$ significantly inhibited high glucose-induced PAl-1 mRNA expression ( ${ }^{*} P<0.05$ versus glucose $22.2 \mathrm{mM}$ or glucose $22.2 \mathrm{mM}$ with $\beta$-gal). (C) HG induced PAl-1 protein secretion was inhibited by NF-kB inhibitors. Synchronized quiescent VSMC cells were treated with DMEM Low Glucose without Penol Red containing 5.6 and $22.2 \mathrm{mM}$ glucose after pretreatment with or without NF- $\kappa B$ inhibitors, 1 $\mathrm{ng} / \mathrm{ml}$ MG132 or $50 \mu \mathrm{M}$ PDTC. The level of PAI-1 in the media was measured by ELISA. HG induced PAI-1 secretion was significantly reduced by NF-kB inhibitors ${ }^{* *} P<0.05$ glucose $22.2 \mathrm{mM}$ vs glucose 5.6 $\mathrm{mM}$; ${ }^{*} P<0.05$ glucose $22.2 \mathrm{mM}$ vs glucose $22.2 \mathrm{mM}$ with NF-kB inhibitors, $1 \mathrm{ng} / \mathrm{ml}$ MG132 or $50 \mu \mathrm{M}$ PDTC). major causes of vascular complication in diabetes; this can be prevented by intensive early treatment as clearly shown in recent epidemiologic studies (DCCT/EDIC Study Research Group, 2005; Holman et al., 2008). Also, SHARE study showed that the degree of intima-media thickness of the carotid artery is relation of $\mathrm{HbA} 1 \mathrm{c}$ (Gerstein et al., 2003). It suggested that the elevated HbA1c is a strong indicator of proliferation of VSMCs. We showed that proliferation of VSMCs was increased by glucose in a concentration-dependent manner. Furthermore, a high glucose concentration (22.2 mM) significantly stimulated the proliferation of VSMC.

Proliferation and migration of VSMCs are characteristic of progression of atherosclerotic lesion from a fatty streak to a more complex plaque (Glass and Witztum, 2001). A wide spectrum of inflammatory mediators is involved in atherosclerosis. NF- $\kappa B$ is one of the key factors of atherosclerosis detected in VSMCs, macrophages, and endothelial cells from human atherosclerotic lesions (Brand et al., 1996). Even though inflammatory cytokines such as TNF- $\alpha$ (Lee et al., 2011) or advanced glycation endproducts (Yoon et al., 2009) promoted the progression of atherosclerosis through activation of $N F-\kappa B$ pathway, that is not adequate evidences which explain about the direct effect of hyperglycemia itself in diabetic vasculopathy. Therefore, in this

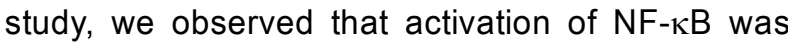
stimulated by high concentrations of glucose as evidenced by translocation of the p65 subunit, increased luciferase activity, and degradation of I $\mathrm{B}-\alpha$. Activation of the $N F-\kappa B$ pathway by high glucose concentrations has been shown in VSMCs from rat (Hattori et al., 2000), swine (Yerneni et al., 1999), and humans (Ruiz et al., 2006). However, the role of $N F-\kappa B$ activation by hyperglycemia in VSMCs has not been clearly shown. We demonstrated that both proliferation and PAI-1 expression of VSMC were mediated by $N F-\kappa B$ activation. Several studies showed that a link between high glucose induced $N F-\kappa B$ activation and cell proliferation was blocked by use of antioxidant or anti-inflammatory drugs such as $\alpha$-lipoic acid (Kim et al., 2007), pentoxifylline, and c-peptide (Cifarelli et al., 2008). These NF-кB blockades are non-specific inhibitors and may influence other intracellular pathways. Thus, we overexpressed a mutant form of $I_{\kappa} B \alpha$, Adl $\mathrm{B}-\alpha \mathrm{M}$. Other investigators showed that cytokine- or growth factor-induce VSMC proliferation is inhibited by liposomal delivery of an NF-кB inhibitory peptide, $I_{\kappa} \mathrm{B} \alpha$ (Selzman et al., 1999). However, this study showed for the first time that high glucose-induced proliferation and $\mathrm{PAl}-1$ expression was prevented by expression of $A d l_{\kappa} B-\alpha M$, an $I_{\kappa} B \alpha$ super-repressor. 
Even though progression of atherosclerotic lesions can lead to ischemic symptoms as a result of progressive narrowing of the vessel lumen, acute cardiovascular events usually results from plaque rupture and thrombosis. Decreased fibrinolysis is believed to accelerate arterial atherosclerosis by facilitating thrombosis. PAI-1 is one of the major regulators of fibrinolysis (Meigs et al., 2000). Levels of plasma PAI-1 are elevated under various thrombotic conditions as well as during diabetes and insulin resistance (Irigoyen et al., 1999). Even though platelets account for more than $90 \%$ of PAI-1 in blood, high glucose increases PAI-1 synthesis in arterial wall cells in culture by activating MAPK and PKC (Suzuki et al., 2002). We showed that PAl-1 gene expression was increased by glucose in a concentration-dependent manner. High glucose concentrations (16.7 and $22.2 \mathrm{mM}$ ) significantly increased the expression of PAI-1. Inhibition of NF-kB prevented PAI-1 expression. Recently, the association between PAI-1 and VSMC proliferation was shown by Chen et al. (2006). PAl-1 transgenic mice show increased VSMC proliferation through NF-KB and ERK. According to our data, inhibition of NF-kB prevented high glucose-induced proliferation and PAl-1 expression in VSMCs. We did not study about the direct effect of PAI-1 on the high glucose-induced proliferation of VSMC. We just demonstrated that increased PAI-1 expression and proliferation induced by high glucose were mediated through NF-kB activation. However, the direct role of PAI-1in the proliferation of VSMCs is very conflicted and complex. Several researchers showed the role PAI-1 as an inhibitor of vascular proliferation. Stefansson and Lawrence (1996) showed that PAI-1 binds vitronectin (VN) and blocks its interactions with u-PAR (urokinase-type plasminogen activator receptor) and $\alpha \gamma \beta 3$ integrin thus inhibiting migration and cell detachment. Wu et al. (2009) showed that active stable mutant recombinant PAI-1 inhibited VSMC proliferation which was lost in VN-deficient VSMCs. On the other hand, overexpression of PAI-1 increased proliferation of VSMC due to a direct inhibitory effect of PAI-1 on the activity of caspase-3. Meilhac et al. (2003) showed pericellular plasmin induced smooth muscle cell anoikis which is a kind of apoptosis induced by detachment of adherent cells from extracellular matrix. This plasminogen activator-induced proteolysis can result plaque rupture and aneurismal formation. It suggests that PAI-1 can enhance proliferation primarily by controlling proteolytic activity. Therefore the balance between PAI-1's inhibitory action on plasmin and interaction with vitronectin and other proteases may play a critical role in interfering with vascular proliferative responses. This PAI-1 paradox is speculated as several ways. Diebold et al. (2008) suggested dose dependent effect of PAI-1 and Konstantinides et al. (2002) argued the different effect of PAl-1 by various stage of atherosclerosis.

Even though we did not elucidate the direct role of PAI-1 in the VSMC proliferation, NF-KB activation directly increased VSMC proliferation through enhancing $\mathrm{Bcl}-2$ expression. Antiapototic effect of $\mathrm{NF}-\mathrm{kB}$ was reported that the activation of NF-kB directly stimulated antiapoptotic protein, $\mathrm{Bcl}-2$ in macrophage (Lawrence et al., 2005). Our results mean that activation of $\mathrm{NF}-\kappa \mathrm{B}$ represents another mechanism of high glucose-induced PAI-1 expression in VSMC.

In conclusion, we have demonstrated that high glucose-induced proliferation and PAI-1 expression in VSMC was prevented by inhibition of NF- $\kappa B$ activation. Direct administration of selective inhibitory

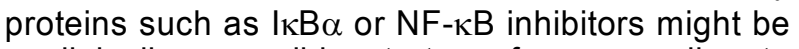
a clinically-accessible strategy for responding to vascular events in diabetic patients.

\section{Methods}

\section{Animals}

8-week old male Sprague-Dawley rats were used after adaptation for 7 days in an animal facility kept at $24-26^{\circ} \mathrm{C}$ and $60 \%$ humidity with 12 -h light /dark cycles.

\section{Isolation and culture of VSMCs}

VSMCs were isolated from the aorta of male SD rats using an enzyme solution mixed with collagenase type I and elastase type III (Yoo et al., 1997). Isolated VSMCs were cultured in Dulbecco's Modified Eagle's Medium (DMEM: Gibco) containing normal glucose (NG; $5.6 \mathrm{mM}$ ), $10 \%$ fetal bovine serum (FBS; Gibco), $100 \mathrm{U} / \mathrm{ml}$ penicillin and 100 $\mu \mathrm{g} / \mathrm{ml}$ streptomycin in a $\mathrm{CO}_{2}$ incubator $\left(5 \% \mathrm{CO}_{2}, 95 \% \mathrm{O}_{2}\right.$, $37^{\circ} \mathrm{C}$ ). These VSMCs were shaped so that they had a 'hill-and-valley' appearance. At passages 5-12, the cells were used for this experiment.

\section{MTT assay}

VSMC proliferation was measured by an MTT (3-(4, 5-dimethylthiazol-2-yl)-2, 5-diphenyl tetrazolium bromide) assay to compare the effect of normal glucose (NG; $5.6 \mathrm{mM}$; D-glucose, Sigma, St. Louis, MO) and high glucose (HG; 11.1, 16.7, and $22.2 \mathrm{mM}$ ) on the cell proliferation.

VSMCs were cultured in 10\% FBS-DMEM (Gibco) on 96-well plates $\left(5 \times 10^{3}\right.$ cells/well). When the VSMCs reached a $60 \%$ confluent state, the cells were rendered quiescent by incubation in DMEM (Gibco) containing NG and $0.1 \%$ FBS for $24 \mathrm{~h}$. Next, the VSMCs were treated with different glucose concentrations $(5.6,11.1,16.7$, and 
$22.2 \mathrm{mM}$ ) for $48 \mathrm{~h}$ in the absence or presence of NF-kB inhibitors: $1 \mathrm{ng} / \mathrm{ml}$ MG132 (Calbiochem, La Jolla, CA) or 50 $\mu \mathrm{M}$ PDTC (Sigma) or Adl $\kappa B-\alpha M$ (kindly provided by Dr. Myung-Shik Lee). $1 \mu \mathrm{M}$ MG-132 or $50 \mu \mathrm{M}$ PDTC was used to treat the cells $2 \mathrm{~h}$ before glucose treatment. After aspiration of supernatants, VSMCs were treated with indicated concentrations of glucose for $48 \mathrm{~h}$. The cells of 96 wells were incubated with $100 \mu \mathrm{l}$ of $0.5 \mathrm{mg} / \mathrm{ml} \mathrm{MTT}$ at $37^{\circ} \mathrm{C}$ for 4 h, washed with cold PBS, and lysed with $100 \mu$ of DMSO (Sigma). After the insoluble crystals were completely dissolved, the optical density of each well was immediately measured at $570 \mathrm{~nm}$ using an automatic micro-plate reader (Molecular Devices, Sunnyvale, CA).

\section{Adenoviral transfection of AdlkB- $\alpha M$}

Adl $\kappa \mathrm{B}-\alpha \mathrm{M}$, an adenoviral vector encoding an $\mathrm{I} \mathrm{B}-\alpha$ mutant protein as an $1 \kappa B \alpha$ super-repressor, whose serine 32,36 were replaced with alanines and control virus (Ad $\beta$-gal). Adenovirus was propagated in HEK 293 cells and concentrated by standard $\mathrm{CsCl}$ ultracentrifugation. VSMCs were infected with Adl $\kappa B-\alpha M$ at a multiplicity of infection of 100 in a serum free media for $4 \mathrm{~h}$. After incubation of $24 \mathrm{~h}$, the cells were treated with indicated glucose before MTT assays.

\section{NF-kB activity}

Immunohistochemical staining: VSMCs were cultured in chamber slides (500 cells/chamber, Lab-Tek; Nalge Nunc International, IL) in 10\% FBS-DMEM (Gibco) for $48 \mathrm{~h}$ and were made quiescent by incubation in DMEM (Gibco) containing NG and $0.2 \%$ BSA for $24 \mathrm{~h}$. The cells were then treated with 5.6 and $22.2 \mathrm{mM}$ glucose solutions for $6 \mathrm{~h}$. TNF- $\alpha(10 \mu \mathrm{g} / \mathrm{ml})$ was used as a positive control. After treatment, the cells were fixed in $4 \%$ paraformaldehyde, washed with PBS, and incubated with anti-RelA/p65 antibody (Santa Cruz Biotechnology, Santa Cruz, CA) overnight at $4^{\circ} \mathrm{C}$. The cells were then washed and incubated with biotinylated anti-mouse IgG, streptavidin-TRITC, and Hoechst33342. Stained cells were observed using a fluorescence microscope connected to a digital camera and interfaced with a computer, and the number of cells showing nuclear translocation of RelA/p65 was counted by a single observer blinded to the treatment groups.

$N F-\kappa B$ reporter assay: $N F-\kappa B$ reporter activity was measured using the Dual-Luciferase Reporter Assay System (Promega, Fitchburg, WI). VSMC were co-transfected with $0.5 \mu \mathrm{g}$ of an NF-kB-responsive reporter gene construct carrying two copies of $\kappa B$ sequences linked to the luciferase gene ( $\mathrm{pNF} \kappa \mathrm{B}$-Luc; Stratagene, La Jolla, CA) along with $0.01 \mu \mathrm{g}$ of Renilla luciferase (Prl-TK; Promega) using Lipofectamine (Invitrogen, Grand Island, NY). At $24 \mathrm{~h}$ after transfection, cells were treated with NG or HG (22.2 mM) for an additional $5 \mathrm{~h}$. Afterward, activities of the luciferase and Renilla luciferase were measured using the Dual-Luciferase Reporter Assay Kit (Promega). Results were presented as luciferase activity normalized to Renilla luciferase activity.

Western blotting: VSMCs were cultured in a 6-well plate (2 $\times 10^{5}$ cells/well) and made quiescence in DMEM contain- ing $0.1 \%$ FBS and NG, then treated with high glucose (HG: $22.2 \mathrm{mM})$ for various times $(0,10,20,30,50$, and $60 \mathrm{~min})$. Following treatment, whole cell lysates were made; protein concentrations were determined and an equal amount of each sample was subjected to SDS-polyacrylamide gel electrophoresis and transferred to nitrocellulose membranes. Following the transfer, the membranes were reversibly stained with a Ponceau S solution (Amresco, Ohio) to confirm sample loading and gel transfer equivalence. After blocking with $5 \%$ nonfat milk for $1 \mathrm{~h}$, the membranes were incubated with an anti-IкB- $\alpha$ antibody $(1: 1,000$, Santa Cruz, $\mathrm{CA}$ ) for overnight at $4^{\circ} \mathrm{C}$ and followed by incubation with an goat-anti-rabbit Ig $G$ secondary antibody $(1: 2,000$, Santa Cruz, CA) for $1 \mathrm{~h}$. Antibody binding was detected by enhanced chemiluminescence (ECL, Pierce). X-ray film (Kodak) was used to visualize the bands. Densitometry quantification values (Image $\mathrm{J}$, program from $\mathrm{NIH}$ ) were measured and shown by fold over the control for each time point.

\section{RNA isolation, semi-quantitative reverse transcription (RT)-polymerase chain reaction (PCR), and real-time RT-PCR of PAl-1 mRNA}

Total RNA was isolated from VSMCs $\left(2.5 \times 10^{5}\right.$ cells $/ 60$ $\mathrm{mm}$ dish/2 $\mathrm{ml}$ DMEM with $0.1 \%$ FBS) that had been serum-starved overnight in $0.1 \%$ FBS and treated with HG $(22.2 \mathrm{mM})$ for $0,2,4,6,8 \mathrm{~h}$. The method was based on the phenol/guanidine isothiocyanate based on RNAzol B (Cinna/Biotecx, Houston, TX) after VSMCs were treated with indicated concentrations of glucose for $6 \mathrm{~h}$ with or without NF-kB inhibitors such as MG132 or Adl $\kappa B-\alpha M$ transfected cells. Total RNA $(1 \mu \mathrm{g})$ was reverse transcribed using MMLV reverse transcriptase (Gibco) with random hexamer priming. For semi-quantitative PCR, aliquots of cDNA were amplified in a $20 \mu \mathrm{l}$ PCR mixture according to the protocol provided by the manufacturer (TaKaRa Bio, Kyoto, Japan). The PCR conditions for PAI-1 were as follows: 28 cycles at $95^{\circ} \mathrm{C}$ for $45 \mathrm{~s}, 60^{\circ} \mathrm{C}$ for $45 \mathrm{~s}$, and $72^{\circ} \mathrm{C}$ for $45 \mathrm{~s}$. PCR products were separated by electrophoresis on $1.5 \%$ agarose gels containing ethidium bromide, and the bands were visualized under UV light. The primers were synthesized by Bioneer Co. Ltd (Seoul, South Korea).

For real-time RT-PCR, the resultant CDNA was amplified using a Roche Light Cycler (Roche Diagnostics Ltd., Lewes, UK). Real-time PCR analysis was carried out with SYBR Green I (Roche Diagnostics Ltd.) and primers for rat PAI-1 (5'-ATGAGATCAGTACTGCGGACGCCATCTTTG-3', 5'-ACAAGTCTGATGGTAGCACCATCTCCGTGC-3') or $\beta$-actin (5'-AATGCCTCCTGCACCACCAAC-3', 5'-AAGGCCATGCCAGTGAGCTTC-3'). PCR reactions with SYBR Green I and primers were performed in a $20 \mu \mathrm{l}$ volume with $2 \mu \mathrm{l}$ CDNA, $0.5 \mu \mathrm{M}$ primers, and $4 \mathrm{mM} \mathrm{MgCl}_{2}$. Taq polymerase, PCR buffer, dNTPs and SYBR Green I dye were included in the Light Cycler-Fast Start DNA Master SYBR Green I mix (Roche Diagnostics Ltd.). Thermal cycling profile consisted of a pre-incubation step at $95^{\circ} \mathrm{C}$ for $10 \mathrm{~min}$ followed by 40 or 50 cycles of a $95^{\circ} \mathrm{C}$ denaturation step for $10 \mathrm{~s}, 59^{\circ} \mathrm{C}$ annealing step for $5 \mathrm{~s}$, and $72^{\circ} \mathrm{C}$ extension step for $20 \mathrm{~s}$. After each extension step, the temperature was raised to $88^{\circ} \mathrm{C}$ to measure SYBR Green I fluorescence at a temperature $2^{\circ} \mathrm{C}$ below the product $\mathrm{Tm}$ and above the $\mathrm{Tm}$ of the pri- 
mer-dimers to prevent interference from non-specific primers-dimers. At the end of the PCR, a melting curve analysis was performed by gradually increasing the temperature from $65^{\circ} \mathrm{C}$ to $95^{\circ} \mathrm{C}\left(0.1^{\circ} \mathrm{C} / \mathrm{s}\right)$ to confirm the amplification specificity of the PCR products. The level of expression of each mRNA and their estimated crossing points $(C p)$ for each sample were determined relative to the standard preparation using LightCycler computer software (v 3.5). The PCR standards for PAI- 1 and $\beta$-actin consisted of a known number of PCR products and were made to a concentration of $10^{8}$ copies/ $\mu$ l. PCR amplification was performed with a series of standards prepared by successive dilutions, and a linear standard curve was automatically generated. A standard curve was constructed for each PCR run. All samples to be compared were run in the same assay.

\section{ELISA of PAI-1 protein}

The levels of PAI-1 in the culture media were determined by ELISA kit (Molecular Innovations). VSMC cells were cultured in 10\% FBS-DMEM Low Glucose without Penol Red (GIBCO) and cells were made quiescent by incubation in DMEM Low Glucose without Penol Red containing $0.1 \%$ FBS and NG for $24 \mathrm{~h}$ and were treated with 5.6 and 22.2 $\mathrm{mM}$ glucose solutions for $4,8,12 \mathrm{~h}$. PAl-1 concentrations of the culture medium were determined using a rat PAI-1 ELISA kit and were expressed as nanograms of active PAl-1 released from VSMC/mg of cell protein. Also, synchronized quiescent VSMC cells were treated with DMEM Low Glucose without Penol Red containing 5.6 and $22.2 \mathrm{mM}$ glucose for $12 \mathrm{~h}$ after pretreatment with or without NF- $\kappa B$ inhibitors, $1 \mathrm{ng} / \mathrm{ml}$ MG132 or $50 \mu \mathrm{M}$ PDTC. The level of PAI-1 in the media was measured by ELISA. HG induced PAI-1 secretion was significantly reduced by NF-кB inhibitors $\left({ }^{* *} P<0.05\right.$ glucose $22.2 \mathrm{mM}$ vs glucose 5.6 $\mathrm{mM}$; ${ }^{*} P<0.05$ glucose $22.2 \mathrm{mM}$ vs glucose $22.2 \mathrm{mM}$ with NF-kB inhibitors, $1 \mathrm{ng} / \mathrm{ml} \mathrm{MG132}$ or $50 \mu \mathrm{M}$ PDTC).

\section{Statistical analysis}

Results were expressed as means \pm SD. Statistical significance was assessed with a non-parametric Student's $t$-test or one-way analysis of variance (ANOVA) using Prism software (Graphpad, San Diego, CA). $P<0.05$ was considered statistically significant. Tukey-Kramer post-tests were performed when appropriate.

\section{Acknowledgements}

This work was supported by a grant from Korean Diabetes Association in 2003 and Kyung Hee University in 2006 (KHU-20060484).

\section{References}

Brand K, Page S, Rogler G, Bartsch A, Brandl R, Knuechel $R$, Page M, Kaltschmidt C, Baeuerle PA, Neumeier D. Activated transcription factor nuclear factor-kappa $B$ is present in the atherosclerotic lesion. J Clin Invest 1996; 97:1715-22
Brand K, Page S, Walli AK, Baeuerle PA. Role of nuclear factor- $\kappa B$ in atherosclerosis. Exp Physiol 1997;82:297-304

Breuss JM, Cejna M, Bergmeister H, Kadl A, Baumgartl G, Steurer S, Xu Z, Koshelnick Y, Lipp J, De Martin R, Losert U, Lammer J, Binder BR. Activation of nuclear factor-kappa B significantly contributes to lumen loss in a rabbit iliac artery balloon angioplasty model. Circulation 2002;105:633-8

Chen Y, Budd RC, Kelm RJ Jr, Sobel BE, Schneider DJ. Augmentation of proliferation of vascular smooth muscle cells by plasminogen activator inhibitor type 1 . Arterioscler Thromb Vasc Biol 2006;26:1777-83

Cifarelli V, Luppi P, Tse HM, He J, Piganelli J, Trucco M. Human proinsulin C-peptide reduces high glucose-induced proliferation and NF-kappaB activation in vascular smooth muscle cells. Atherosclerosis 2008;201:248-57

Diebold I, Kraicun D, Bonello S, Görlach A. The 'PAI-1 paradox' in vascular remodeling. Thromb Haemost 2008; 100:984-91

Erl W, Hannson GK, de Martin R, Draude G, Wever KSC, Weber $G$. Nuclear factor $-\kappa B$ regulates induction of apoptosis and inhibitor of apoptosis proteon-1 expression in vascular smooth muscle cells. Circ Res 1999;84:668-77

Feener EP, King GL. Vascular dysfunction in diabetes mellitus. Lancet 1997;350:SI9-I13

Gerstein HC, Anand S, Yi QL, Vuksan V, Lonn E, Teo K, Malmberg K, McQueen M, Yusuf S; SHARE Investigators. The relationship between dysglycemia and atherosclerosis in South Asian, Chinese, and European individuals in Canada: a randomly sampled cross-sectional study. Diabetes Care 2003;26:144-9

Glass CK, Witztum JL. Atherosclerosis. The road ahead. Cell 2001;104:503-16

Hattori Y, Hattori S, Sato N, Kasai K. High glucose-induced nuclear factor $\kappa B$ activation in vascular smooth muscle cells. Cardiovas Res 2000;46:188-97

Holman RR, Paul SK, Bethel MA, Matthews DR, Neil HAW. 10 -year follow-up of intensive glucose control in type 2 diabetes. N Engl J Med 2008;359:1577-89

Irigoyen JP, Muñoz-Cánoves P, Montero L, Koziczak M, Nagamine $Y$. The plasminogen activator system: biology and regulation. Cell Mol Life Sci 1999;56:104-32

Jeong IK, King GL. New perspectives on diabetic vascular complications: the loss of endogenous protective factors induced by hyperglycemia. Diabetes Metab J 2011;35:8-11

Kim HS, Kim HJ, Park KG, Kim YN, Kwon TK, Park JY, Lee $\mathrm{KU}$, Kim JG, Lee IK. Alpha-lipoic acid inhibits matrix metalloproteinase- 9 expression by inhibiting NF-kappaB transcriptional activity. Exp Mol Med 2007;39:106-13 Konstantinides S, Schäfer K, Loskutoff DJ. Do PAI-1 and vitronectin promote or inhibit neointima formation? The exact role of the fibrinolytic system in vascular remodeling remains uncertain. Arterioscler Thromb Vasc Biol 2002;22:1943-5

Landry DB, Couper LL, Bryant SR, Lindner V. Activation of the NF-kappa B and I kappa B system in smooth muscle cells after rat arterial injury. Induction of vascular cell adhesion molecule-1 and monocyte chemoattractant protein-1. Am J 
Pathol 1997;151:1085-95

Lawrence T, Bebien M, Liu GY, Nizet V, Karin M. IKKalpha limits macrophage NF-kappaB activation and contributes to the resolution of inflammation. Nature 2005;434:1138-43

Lenardo MJ, Baltimore D. NF-кB: a pleiotropic mediator of inducible and tissue specific gene control. Cell 1989;58: 227-9

Lee CW, Lin CC, Lee IT, Lee HC, Yang CM. Activation and induction of cytosolic phospholipase A2 by TNF- $\alpha$ mediated through Nox2, MAPKs, NF- $\mathrm{BB}$, and p300 in human tracheal smooth muscle cells. J Cell Physiol 2011;226:2103-14

Lee KM, Seo HY, Kim MK, Min AK, Ryu SY, Kim YN, Park YJ, Choi HS, Lee KU, Park WJ, Park KG, Lee IK. Orphan nuclear receptor small heterodimer partner inhibits angiotensin II-stimulated PAI-1 expression in vascular smooth muscle cells. Exp Mol Med 2010;42:21-9

Ma LJ, Mao SL, Taylor KL, Kanjanabuch T, Guan Y, Zhang Y, Brown NJ, Swift LL, McGuinness OP, Wasserman DH, Vaughan DE, Fogo AB. Prevention of obesity and insulin resistance in mice lacking plasminogen activator inhibitor 1. Diabetes 2004;53:336-46

Meigs JB, Mittleman MA, Nathan DM, Tofler GH, Singer DE, Murphy-Sheehy PM, Lipinska I, D'Agostino RB, Wilson PW. Hyperinsulinemia, hyperglycemia, and impaired hemostasis: the Framingham Offspring Study. JAMA 2000;283:221-8

Meilhac O, Ho-Tin-Noé B, Houard X, Philippe M, Michel JB, Anglés-Cano E. Pericellular plasmin induces smooth muscle cell anoikis. FASEB J 2003;17:1301-3

Monaco C, Paleolog E. Nuclear factor kappaB: a potential therapeutic target in atherosclerosis and thrombosis. Cardiovasc Res 2004;61:671-82

Pandolfi A, Cetrullo D, Polishuck R, Alberta MM, Calafiore A, Pellegrini G, Vitacolonna E, Capani F, Consoli A. Plasminogen activator inhibitor type 1 is increased in the arterial wall of type II diabetic subjects. Arterioscler Thromb Vasc Biol 2001;21:1378-82

Ross R. Atherosclerosis-an inflammatory disease. N Engl J Med 1999;340:115-26

Ruiz E, Gordillo-Moscoso A, Padilla E, Redondo S, Rodriguez E, Reguillo F, Briones AM, van Breemen C, Okon E, Tejerina T. Human vascular smooth muscle cells from diabetic patients are resistant to induced apoptosis due to high $\mathrm{Bcl}-2$ expression. Diabetes 2006;55:1243-51

Selzman $\mathrm{CH}$, Shames BD, Mclntyre RC Jr, Banerjee A, Harken AH. The NFkappaB inhibitory peptide, IkappaBalpha, prevents human vascular smooth muscle proliferation. Ann Thorac Surg 1999;67:1227-31

Stefansson S, Lawrence DA. The serpin PAI-1 inhibits cell migration by blocking integrin alpha $\mathrm{V}$ beta 3 binding to vitronectin. Nature 1996;383:441-3

Suzuki M, Akimoto K, Hattori Y. Glucose upregulates plasminogen activator inhibitor-1 gene expression in vascular smooth muscle cells. Life Sci 2002;72:59-66

The Diabetes Control and Complications Trial/Epidemiology of Diabetes Interventions and Complications (DCCT/EDIC) Study Research Group. Intensive diabetes treatment and cardiovascular disease in patients with type 1 diabetes. $\mathrm{N}$ Engl J Med 2005;353:2643-53

UK Prospective Diabetes Study (UKPDS) Group. Intensive blood-glucose control with sulphonylureas or insulin compared with conventional treatment and risk of complications in patients with type 2 diabetes (UKPDS 33). Lancet 1998;352:837-53

Wu J, Peng L, McMahon GA, Lawrence DA, Fay WP. Recombinant plasminogen activator inhibitor-1 inhibits intimal hyperplasia. Arterioscler Thromb Vasc Biol 2009;29: 1565-70

Yerneni KK, Bai W, Khan BV, Medford RM, Natarajan R. Hyperglycemia-induced activation of nuclear transcription factor kappaB in vascular smooth muscle cells. Diabetes 1999;48:855-64

Yoo HJ, Kozaki K, Akishita M, Watanabe M, Eto M, Nagano K, Sudo N, Hashimoto M, Kim S, Yoshizumi M, Toba K, Ouchi $\mathrm{Y}$. Augmented $\mathrm{Ca} 2+$ influx is involved in the mechanism of enhanced proliferation of cultured vascular smooth muscle cells from spontaneously diabetic Goto-Kakizaki rats. Atherosclerosis 1997;131:167-75

Yoon SJ, Yoon YW, Lee BK, Kwon HM, Hwang KC, Kim M, Chang W, Hong BK, Lee YH, Park SJ, Min PK, Rim SJ. Potential role of HMG CoA reductase inhibitor on oxidative stress induced by advanced glycation endproducts in vascular smooth muscle cells of diabetic vasculopathy. Exp Mol Med 2009;41:802-11 